Original research article

\title{
How patients with laryngeal cancer evaluate their quality of life
}

\author{
Jana Škvrňáková ${ }^{1,2}{ }^{*}$, Lenka Teichmanová ${ }^{1}$, Iva Bártová ${ }^{2}$ \\ ${ }^{1}$ University of Pardubice, Faculty of Health Studies, Department of Nursing, Pardubice, Czech Republic \\ ${ }^{2}$ Regional Hospital in Pardubice, JSC, Pardubice Hospital, Department of Otorhinolaryngology and Head and Neck Surgery, Pardubice, Czech Republic
}

\begin{abstract}
The aim of the study was to find out the quality of life in patients with laryngeal cancer after the treatment and to compare it with the quality of life of the general population of the same average age.

Data collection was conducted through a cross-sectional quantitative survey using the standardized World Health Organization Quality of Life Questionnaire (WHOQOL-BREF), including the population standards for the age groups. Data collection was undertaken in patients treated at the Otorhinolaryngological Department. Data from 42 patients, with an average age of 70 (16 patients with permanent tracheostomy) were evaluated. A $t$-test was used for the statistical evaluation of the quality of life in patients after the treatment of laryngeal cancer and the general population of the same average age.

We found out that patients displayed a higher quality of life in most areas of the WHOQOL-BREF (physical health, psychological health, social relationships, environment, and overall quality of life and health). A difference was found in the area of physical health, which patients rated lower than the other surveyed areas. The use of the paired $t$-test for equal and unequal variances demonstrated a statistically significant difference in the subjective WHOQOL-BREF assessment of the quality of life between patients after the treatment of laryngeal cancer and the general population of the given average age.

From a practical point of view (clinical intervention), it cannot be clearly stated that the results of the quality of life of patients after the treatment of laryngeal cancer are significantly different from the values of the given average age population.
\end{abstract}

Keywords: Laryngeal cancer; Population Standard for Quality of Life; Quality of Life; WHOQOL-BREF

\section{Introduction}

Malignant tumours account for a quarter of all deaths in the Czech Republic (CR) and are the second leading cause of death (after cardiovascular diseases). In the Czech Republic, 27.3 thousand people died of cancer in 2017. Out of the total annual deaths, the cause of death was cancer-related in $27.0 \%$ of men and $22 \%$ of women (IHIS CR, 2018a). The year-onyear growth rate of newly diagnosed malignant tumours per 100 thousand inhabitants increased by $0.1 \%$ in men and by $2 \%$ in women (IHIS CR, 2018b).

In 2017, the incidence rate of laryngeal cancer was 2.65 per 100 thousand inhabitants worldwide, 3.75 in Europe and 4.9 in the Czech Republic (IHIS CR, 2018b). According to a survey by the Institute of Health Information and Statistics of the Czech Republic, up to $60 \%$ of patients are diagnosed with laryngeal tumours at an advanced stage. The reason for this may be an asymptomatic period of early disease, but also a lack of prevention in terms of little awareness and a lack of screening programmes for laryngeal cancer.
The above-stated epidemiology both in the Czech Republic and in the world clearly indicates that laryngeal cancer is one of the most frequently occurring diseases, which is why it became the focus of our research.

Oncological disease always imposes a heavy burden on the patients and their family in all areas of life. The perception of the quality of life is subjective and may conflict with objective symptoms and findings. Therefore, in addition to evaluating the effect of treatment, the quality of life of patients should be monitored. Then, on the basis of the results, other methods and procedures in the provision of health care should be implemented to maintain or improve the patient's quality of life (Gurková, 2011).

The quality of life in general and the quality of life of patients with head and neck cancer are dealt with in a number of professional monographs and studies, both in the Czech Republic and abroad. In the evaluation of quality of life in patients with total laryngectomy with permanent tracheostomy, where a non-specific standardized questionnaire Schedule for Evaluation of Individual Quality of Life (SEIQoL) was used, Čiháková and Čelakovský (2007) concluded that tracheostomy

\footnotetext{
* Author for correspondence: Jana Škvrňáková, University of Pardubice, Faculty of Health Studies, Department of Nursing Jiř́ho z Poděbrad 2587, 53002 Pardubice, Czech Republic; e-mail: jana.skvrnakova@upce.cz http://doi.org/10.32725/kont.2019.045 
worsens the quality of life, although not as severely as to make life with a tracheostomy unbearable.

A number of foreign studies have investigated the effect of treatment on quality of life. One example is the randomized study of Bottomley et al. (2014), which involved 6 European countries, 19 institutions and 450 respondents. The respondents were patients with laryngeal cancer or cancer of the laryngeal part of the pharynx following surgical resection. The quality of life was evaluated by standardized questionnaires of the European Organization for Research and Treatment of Cancer (EORTC QLQ-C30, version 3) and Quality of Life Head and Neck Module (QLQ-H35) at intervals of 42 days, 6, 12, 24, 36 and 48 months after the treatment. Patients were divided into 2 groups according to the follow-up treatment. The first group comprised patients with radiotherapy and sequential induction chemotherapy, and the second group comprised patients undergoing chemoradiotherapy. There were no differences in the quality of life among respondents of both groups concerning fatigue and shortness of breath. The differences in quality of life were associated with swallowing and speech, with better results in patients with sequential induction chemotherapy and radiotherapy. However, most differences in the quality of life between the two groups of patients were not found in the evaluation after 48 months of treatment (Bottomley et al., 2014). Research surveys assessing the quality of life associated with treatment procedures are used to find the optimal course of therapy while maintaining the highest quality of life.

A factor significantly influencing the perception and evaluation of patients' quality of life is marital status. Farrand and Duncan (2007) compared the quality of life in 226 patients after a total laryngectomy compared to a control group of 89 healthy respondents. In the group of patients with a total laryngectomy, $66.8 \%$ were married, while the control group included $65.2 \%$ married respondents. The quality of life was assessed according to the non-specific standardized Short Form 36 Health Survey (SF-36), where, among other things, the social functions and emotional role limitations were evaluated. In patients with total laryngectomy, the mean value was $\varnothing 72.63$ in the area of social functions and $\varnothing 61.41$ for the emotional role limitations. The mean values of the control group, i.e. healthy respondents, were $\varnothing 79.24$ for social functions and $\varnothing 82.21$ for emotional role limitations. The social and emotional area in patients after total laryngectomy is influenced by a number of factors, such as the adoption of an alternate form of communication, the prognosis of the disease, the patient's attitude to the disease, loss of employment, etc. According to the authors of the study, a significant role in coping with a difficult life situation, i.e. a serious disease, is played by family and friends. Furthermore, the authors of the study suggested that patients using functional tracheoesophageal puncture to communicate will have the highest quality of life. Out of the total 226 respondents, 147 used tracheoesophageal puncture for communication, 42 communicated using oesophageal speech, and 37 had electrolarynx. Quality of life results showed that further improvement in voice quality did not affect the general quality of life in all SF-36 rated areas. However, all three groups of respondents with alternate communication mechanisms had a worse quality of life than the control group (respondents without laryngeal diseases) (Farrand and Duncan, 2007).

Van den Brink et al. (2006) evaluated the quality of life in 90 patients in the first three months following discharge after surgery for head and neck cancer in the Netherlands. They used the Quality of Life (QOL) standard questionnaire, and found respondents living alone to have reduced quality of life, especially in the following areas: fear associated with the specificity of the head and neck disease, concerns about contact with nursing staff, physical appearance, low confidence in the ability to communicate with others and loneliness.

Ulrich and Canale (2005) recommend, in the absence of partner support, to provide patients with systematic attention of nursing staff, and to draw up a management plan on admission to reduce risk and provide support.

An extensive retrospective study by Gourin et al. (2015), which assessed the quality of care provided in patients with laryngeal cancer associated with dysphagia, weight loss, oesophageal strictures, etc., was conducted in the United States. Data were collected on patients diagnosed with laryngeal carcinoma in 2004-2007. The study included a total of 2,370 patients. The quality of care provided was monitored after treatment for 30 days, followed by intervals of 1, 2, 3, 4 and 5 years. The number of respondents in the last year of the evaluation was 275. The authors of the study report that the higher quality of care provided is associated with a lower risk of dysphagia, weight loss, airway obstruction, and pneumonia associated with a tracheostomy. The retrospective study also looked at the impact of provided care on the cost of long-term care for these patients.

Veldhuis et al. (2016) assessed the quality of life using non-specific and specific standardized quality of life questionnaires in two groups of patients. The first group of respondents comprised patients with laryngeal cancer and the other group comprised patients with cancer of the oropharynx. EORTC QLQ-C30 (version 3) and specific standardized QLQ-H\&N35 questionnaire were used to assess the quality of life before the treatment and then 10 months after treatment. The survey showed that the overall quality of life in both groups of respondents assessed by the EORTC QLQ-C30 questionnaire was reduced to 53.4 at the beginning of the treatment, and then improved to 60.2 ten months after the treatment, $p<0.05$. The differences were found using the specific QLQH\&N35 assessing factors directly associated with head and neck cancer. Oropharyngeal cancer patients reported greater fatigue and oral cavity problems, laryngeal cancer patients lost their sense of smell, taste, and suffered from a cough. Veldhuis et al. (2016) assess the overall quality of life for both groups of respondents after the treatment to be at a satisfactory level.

The same quality of life assessing tools EORTC QLQ-C30 and QLQ-H\&N35 were used in a three-year study by Malá et al. (2015), which evaluated the nutritional and clinical status associated with the quality of life of patients with head and neck cancer. The prospective study assessed the quality of life in relation to clinical status and a number of variables and symptoms while focusing on nutrition solutions. Monitoring the quality of life, oncological data, subjective clinical symptoms, comorbidities, and laboratory markers took place in five check-ups over a period of three years. The authors state that early nutritional intervention through enteral nutrition can improve the quality of life, and has a beneficial effect on the further development of malnutrition and survival of patients. At the end of the study, the authors state that monitoring quality of life is extremely valuable for mutual understanding.

Most studies are concerned with the quality of life associated with the type of treatment, site of the tumour, or the extent of surgery. In our research, we wanted to determine the quality of life using a standardized questionnaire in the group of patients after laryngeal cancer compared to the quality of life of the general population of the given age average. This influenced the choice of the tool for assessing the quality of life, even with the awareness of certain limits (use of a non-spe- 
cific standardized questionnaire of quality of life, normative values for the general population in the Czech Republic from 2006, different representation of the level of education among respondents, regional perspective and the size of the municipality, normative values for the population average irrespective of gender of the patients). Unfortunately, there is no other standardized tool for assessing the quality of life in the Czech Republic, which would also set normative values for the general Czech population.

\section{The aim of the research}

The aim of the research was to determine the quality of life in patients with laryngeal cancer after treatment and then to compare it to the general population of the given age average using the abbreviated version of the World Health Organization's Quality of Life Questionnaire (WHOQOL-BREF).

\section{Materials and methods}

The research was carried out in patients treated at the ENT clinic in a regional type hospital, 3 months or more after the treatment, without recurrence of the disease. A total of 55 patients were approached and 47 participated, but 5 of them completed the questionnaires incompletely and were thus excluded from the research. Consequently, the study group consisted of 42 patients with complete data in both questionnaires. Data collection took place from March to December 2016. Data were processed by descriptive statistics and unpaired parametric $t$-test.

Data collection was approved by the ethics committee of the healthcare facility and patients agreed to be included in the research by signing an informed consent.

The questionnaire was filled in by patients during checkups at the oncological counselling centre. The survey included patients without cognitive deficits. The cognitive status was assessed according to medical records, information obtained from healthcare professionals, and an interview during the check-up.

The WHOQOL-BREF Quality of Life Questionnaire, which is an abbreviated version of the WHOQOL-100 questionnaire, was used to assess the quality of life data. The questions are based on 4 domains (physical health, psychological health, social relationships, and environment). The questionnaire contains 26 questions, where the first 2 are separately examined as the overall quality of life and general health (Q1 and Q2). Patients respond to fixed questions using the Likert scale. The range of the scale for individual questions is $1-5$, and for the domains 4-20. The scale of the separately examined questions Q1 and Q2 is 1-5. Higher scores denote a better quality of life. The resulting data is evaluated in the form of domain scores and the two separate questions. The scores are the average totals calculated from the individual answers. Arithmetic means, standard deviation, and variance were used for the calculations. The methodology of Dragomirecká and Bartoňová (2006) was used to generate raw domain scores and transform them into the values 4-20 or 1-5 respectively.

The General Data Questionnaire was used to identify patient data such as employment, social and family situations. Treatment procedures, risk factors of laryngeal carcinoma or problems associated with tracheostomy were also examined. The questionnaire contained a total of 12 questions, with the first 10 questions answered by all patients and the remaining two only by patients with permanent tracheostomy. Closed (dichotomic and polytomic), open and semi-open questions were used.
Medical documentation was used to provide additional information about the patient's previous treatment, cognitive assessment, length of follow-up in the ENT clinic and the age.

Basic identification data about the sample of patients are also stated. A total of 42 patients completed the questionnaire, 3 or more months after treatment, without recurrence. We set this time limit because it allows patients a certain degree of adaptation after the demanding treatment. The group is represented by 39 (93\%) men and $3(7 \%)$ women. There were $26(62 \%)$ patients without a permanent tracheostomy and $16(38 \%)$ with a permanent tracheostomy. The average age of all patients was 70 years, the lowest age was 55 years and the highest was 84 years. Most respondents had elementary education, and 34 (81\%) patients had vocational training. The remaining part of the respondents, 8 (19\%), had secondary or university education. A significant factor affecting the quality of life is the patient's partner. 26 (62\%) respondents reported being married, 16 (38\%) were widows/widowers, divorced or single.

Population QoL standards for the 60-74 age group were based on results from 217 respondents. In establishing population standards, the relationship of WHOQOL-BREF domains to socio-demographic characteristics such as gender, life with a partner, work/study, housing type, and material wealth was examined. A multistage random selection by INRES Agency interviewers was used to select respondents. For respondents of the $60+$ age group, $40 \%$ of respondents considered themselves ill (Dragomirecká and Bartoňová, 2006, p. 19-20).

\section{Results}

In this part, we focus on presenting the quality of life results of our respondents compared to the general population values of the given age average.

Table 1 displays the results of a standardized WHOQOL-BREF questionnaire in our 42 respondents. Domain 1 represents the quality of life in the area of physical health. According to the mean value, it can be said that the quality of life in this area is rather high in our respondents (mean = 13.33). The same is true for domain 2 (psychological health), where the mean value was 15.60 . Domain 3 evaluates social relationships, and even in this case, patients have a higher quality of life. The last domain (domain 4) is the perception of the environment where the mean value was 16.88 . Therefore, it can be said that all patients have a higher quality of life in all domains (min. 4 - max. 20). Also, the area of overall quality of life $($ mean $=3.50)$ and health $($ mean $=3.38)$ is higher $(\min .1$ max. 5). However, when comparing individual domains, it is evident that the quality of life in physical health is somewhat lower than the values attained in the other domains.

Table 1 also displays the results of a standardized WHOQOL-BREF questionnaire for the general population of the given age average. The measured values were taken from the user manual of this questionnaire (Dragomirecká and Bartoňová, 2006). According to the mean value of overall quality of life (3.83) and health (3.33), compared to the general population standard of the Czech Republic, the values in our respondents are rather high. Thus we can assume that our respondents are satisfied with their lives. They rated the quality of life in the area of physical health as the highest (mean = 14.59), followed by psychological health (mean = 14.36) and social relations $($ mean $=14.21$ ). Respondents rated the environment as the worst, even though the mean value was still average at 13.76 . 


\begin{tabular}{|c|c|c|c|c|c|c|c|c|c|}
\hline Patients with laryngeal cancer & $n$ & Mean & Min & $\operatorname{Max}$ & $\begin{array}{c}\text { Population } \\
\text { standard }\end{array}$ & $n$ & Mean & Min & Max \\
\hline Physical domain 1 & 42 & 13.13 & 9.14 & 16.57 & Domain 1 & 217 & 14.59 & 6.68 & 18.86 \\
\hline Psychological domain 2 & 42 & 15.60 & 11.33 & 20 & Domain 2 & 217 & 14.36 & 7.33 & 18.67 \\
\hline Social domain 3 & 42 & 16.03 & 8 & 20 & Domain 3 & 217 & 14.21 & 5.33 & 20 \\
\hline Environment domain 4 & 42 & 16.88 & 11.5 & 20 & Domain 4 & 217 & 13.76 & 8 & 19 \\
\hline Overall QoL (Q1) & 42 & 3.50 & 1 & 5 & Q1 & 217 & 3.83 & 2 & 5 \\
\hline Overall health (Q2) & 42 & 3.38 & 1 & 5 & Q2 & 217 & 3.33 & 1 & 5 \\
\hline
\end{tabular}

$n=$ number of respondents; mean = arithmetic mean; $\min =$ minimum measured value; max = maximum measured value

The population standard for Overall quality of life (Q1) is 3.83, while in our respondents it was 3.50. The population standard for general health (Q2) is 3.33 , while it was 3.38 in laryngeal cancer patients. However, there is a noticeable difference in domain 1 (physical health), where the arithmetic mean value of our respondents is lower (mean $=13.33$ ) than the population standard (mean $=14.59$ ). Interestingly, in other domains (psychological health, social domain and environment domain), the patients after the treatment of laryngeal cancer indicate a higher quality of life than the healthy population of the given age average.

For the statistical evaluation of the quality of life between the group of patients after laryngeal cancer treatment and the general population of the given age average, an unpaired $t$-test was used in domains 1 and 3 for equal variances, and a $t$-test was used in domains 2 and 4 for unequal variances (see Table $2,3,4)$. We compared the calculated $t$ with critical value for the selected significance level $\alpha=0.05$ ( $t_{\text {crit }} 0.05$ ). In all the domains the value $t$ is greater than $t_{\text {crit }} 0.05$. Therefore, the difference in QoL between the patients and the healthy population is statistically significant. For the comparison of the value $t$ with the critical value for significance level $\alpha=0.01$ ( $\left.t_{\text {crit }} 0.01\right)$, $t$ is also greater, and thus it might be said that the difference is statistically highly significant (Table 5). Consequently, there is a statistically highly significant difference between our sample of patients after the treatment of laryngeal cancer and the general population of the given age average in the subjective assessment of the quality of life according to WHOQOL-BREF.

Table 2. Results of WHOQOL-BREF in the general population of the given average age

\begin{tabular}{|c|c|c|c|c|c|c|}
\hline & & $n$ & $v$ & Mean & $S D$ & $\sigma^{2}$ \\
\hline \multirow{4}{*}{$60-74$ years } & Physical domain 1 & 217 & 216 & 14.59 & 2.64 & 6.97 \\
\hline & Psychological domain 2 & 217 & 216 & 14.36 & 2.11 & 4.45 \\
\hline & Social domain 3 & 217 & 216 & 14.21 & 2.30 & 5.29 \\
\hline & Environment domain 4 & 217 & 216 & 13.76 & 2.05 & 4.20 \\
\hline
\end{tabular}

$n=$ number of respondents; $v$ = degrees of freedom; mean = arithmetic mean; $S D=$ standard deviation; $\sigma^{2}=$ statistical variance

Table 3. Results of WHOQOL-BREF in patients with laryngeal cancer

\begin{tabular}{lllllll} 
& & $n$ & $v$ & Mean & $S D$ & $\sigma^{2}$ \\
\hline & Physical domain 1 & 42 & 41 & 13.13 & 1.87 & 3.48 \\
Average age & Psychological domain 2 & 42 & 41 & 15.60 & 1.87 & 3.51 \\
of 70 years & Social domain 3 & 42 & 41 & 16.03 & 3.15 & 9.93 \\
& Environment domain 4 & 42 & 41 & 16.88 & 2.02 & 4.10 \\
\hline
\end{tabular}

$n=$ number of respondents; $v=$ degrees of freedom; mean = arithmetic mean; $S D=$ standard deviation; $\sigma^{2}=$ statistical variance

Table 4. F-test of equality of variances

\begin{tabular}{lcccc} 
& $F$ & $F_{\text {crit }}$ & & Result \\
\hline Physical domain 1 & 2.0027 & 1.6761 & $F>F_{\text {crit }}$ & unequal variance \\
Psychological domain 2 & 1.2671 & 1.6761 & $F<F_{\text {crit }}$ & equal variance \\
Social domain 3 & 1.8768 & 1.5503 & $F>F_{\text {crit }}$ & unequal variance \\
Environment domain 4 & 1.0262 & 1.6761 & $F<F_{\text {crit }}$ & equal variance \\
\hline$F_{\text {crit }}=$ critical value for $F$ & & & & \\
\hline
\end{tabular}


Table 5. Unpaired $t$-test according to equality of variances

\begin{tabular}{lccccc} 
& $t$ & $t_{\text {crit } 0.05}$ & $t_{\text {crit }} 0.01$ & & Notes \\
\hline Physical domain 1 & 4.3079 & 1.9600 & 2.5760 & $t>t_{\text {crit }} 0.01$ & $t$-test for unequal variance \\
Psychological domain 2 & 3.5554 & 1.9692 & 2.5951 & $t>t_{\text {crit }} 0.01$ & $t$-test for equal variance \\
Social domain 3 & 3.5675 & 1.9600 & 2.5760 & $t>t_{\text {crit }} 0.01$ & $t$-test for unequal variance \\
Environment domain 4 & 9.0495 & 1.9692 & 2.5951 & $t>t_{\text {crit }} 0.01$ & $t$-test for equal variance \\
\hline$t_{\text {crit }}$ critical value for $t$ & & & &
\end{tabular}

\section{Discussion}

The literature dealing with head and neck cancer often states that patients with laryngeal cancer display a lower socioeconomic status (Hybášek et al., 2010; Nováková and Laco, 2008; Šlampa and Smilek, 2016). The results of the Czech Population and Housing Census (2011) allow us to compare the educational attainment in the general population of the same age average (70-74 years) with our patient sample. $63.6 \%$ of the population attained primary and vocational education, $25.7 \%$ attained secondary education and $8.3 \%$ attained university education. Out of our patients (with the average age of 70 years), $81 \%$ had elementary education and only $19 \%$ had secondary or university education. This fact confirms the lower education status of our respondents compared to the general population according to the 2011 survey (Czech Statistical Office, 2014).

In British research into the quality of life of patients with total laryngectomy with various alternate communication mechanisms by Farrand and Duncan (2007), out of the 218 respondents, $57.8 \%$ attained elementary or vocational education, while $28.9 \%$ attained university education. University education was attained by $24.7 \%$ of the healthy respondents in the control group. Thus, in a British study, contrary to the results of our research, the number of people with university education suffering from laryngeal cancer did not differ significantly from that in the general population (Farrand and Duncan, 2007).

Our sample of patients was comprised of $93 \%$ men and $7 \%$ women. The representation of our patients by gender is consistent with the proportion of patients with laryngeal cancer diagnosed in the Czech Republic, where the incidence was 8.8 men per 100,000 inhabitants and only 1 woman per 100,000 inhabitants in 2016 . The incidence of laryngeal cancer by age was the same in our group of patients and the patients in the total population of the Czech Republic as of 2016 (i.e. 55-75 years) (IHIS CR, 2017). Although the proportion of women with laryngeal cancer is significantly lower than men, research by Tan et al. (2016) interestingly noticed differences in perception of the quality of life in patients with laryngeal cancer by gender. Data collection took place in Germany, using standardized questionnaires EORTC QLQ-C30 and QLQ-H\&N35. The total number of respondents was 53, of which 8 (15.09\%) were women. Tan et al. (2016), when analyzing results for each gender, concluded that women perceive a significantly worse quality of life. Certainly, this finding would deserve further research into laryngeal cancer in women only.

Laryngeal cancer and the treatment that follows significantly affect the quality of life. If a patient undergoes radical surgery, total or partial laryngectomy, a number of functions are impaired (loss of voice and speech, change in natural breathing pattern, permanent tracheostomy, loss of the respiratory, protective and olfactory functions of the nose, temporary and sometimes permanent swallowing disorder, impaired function of the abdominal muscles) with a considerable impact on the mental and social area. In the long term, the foremost challenge is the complete loss of speech or its significant limitation in case of partial laryngectomy. This is confirmed by a number of research studies (Atteih et al., 2008; Daugaard et al., 2017; Chrobok et al., 2004; Karlsen et al., 2017; Klozar, 2005; Rottenberg et al., 2003; Šlampa and Smilek, 2016; Veldhuis et al., 2016). Another important issue that affects the overall quality of life is a permanent tracheostomy. The patient is educated about the treatment and gradually adapts to breathing through the tracheostomy and the loss of some sensory functions. He or she also has to come to an acceptance of the change of physical appearance, and the reactions of one's family and the wider social environment (Paleri et al., 2006).

Based on the claims of the authors researching quality of life using non-specific standardized questionnaires in patients with head and neck cancer, we assumed that the quality of life of our patients in all examined areas (physical health, psychological health, social relations, and environment) would be worse than that of the population age average. However, this assumption was confirmed only in the first domain (physical health). The negative impact on the quality of life in the area of physical health is evident, particularly as a result of limitations after surgery (total or partial laryngectomy). Patients undergoing conservative treatment (actinotherapy) or combined therapy, in addition to the difficulties arising from surgery, suffer from post-radiation changes in the skin and mucous membranes, which significantly affect food intake, long-term salivation and swallowing. In some patients, actinotherapy leads to permanent damage to saliva formation and the need to use artificial saliva or to drink when swallowing and moisturize the mucous membranes in the oral cavity (Likhterov et al., 2018; Malá et al., 2015; Mandysová and Škvrňáková, 2016; Veldhuis et al., 2016). On the other hand, in the remaining 3 domains (psychological health, social relations, and environment), our respondents reported a higher quality of life than the population standard for the given age average. Similar conclusions were reached by other researchers using a standardized non-specific quality of life questionnaire to assess the quality of life (Čiháková and Čelakovský, 2007; Farrand and Duncan, 2007; Veldhuis et al., 2016).

In research by Kaase and Tóthová (2017), whose aim was to assess the quality of life in patients with rheumatoid arthritis compared to the quality of life in the general population of the Czech Republic, the authors used the same standardized WHOQOL-100 questionnaire in its full version. The authors of the statistical testing concluded that the quality of life of rheumatoid arthritis respondents was negatively affected in terms of physical health and independence. The differences with population standards in other domains (psychological health, social relations, environment, and spirituality), were minimal. 
In a statistical evaluation of the quality of life between our patients and the quality of life of the Czech population, we found a statistically significant difference. This result may be influenced by the different sizes of samples (patients $n=$ 42 , population standard $n=217$ ). Another factor may be the composition of the samples. There are $50 \%$ of men and women in population norms (Dragomirecká and Bartoňová, 2006), while the ratio of men and women in our sample of patients was $93 \%$ to $7 \%$, which corresponds to the incidence of laryngeal cancer in the Czech Republic. This was a deliberate choice of respondents. Furthermore, the result may be distorted by the time when data was collected. The population standards were published in 2006, while the collection of data for our research took place in 2016. Therefore, the results of statistical evaluation of the quality of life in patients with laryngeal cancer may lead to consideration and possibly to new statistical research.

\section{Limitations of the research}

The WHOQOL-BREF standardized questionnaire of the World Health Organization has been available in the Czech Republic since 2006, including the population standards according to age categories. Despite the fact that these are older population standards determined on the basis of a survey conducted in the Central Bohemia Region only, we decided to use this questionnaire. The main reason for this choice was the availability of a standardized version of the questionnaire in Czech language, and also the availability of the population standards for the given age group, which enabled us to compare the data of our patients with the age average. Another reason was the use of a non-specific standardized tool that allowed us to compare the results with the population standard and to evaluate the general areas co-determining the overall quality of life. The limitation of the research was the low number of respondents in the sample. The similarity of our sample of respondents to the general population was in the area of age, not gender. The difference was also in the proportion of respondents according to the highest educational attainment, where in the population standard the representation of respondents with secondary and university educations was $15 \%$ higher than in our sample.

\section{Conclusions}

The aim of this work was to determine the quality of life in patients after treatment of laryngeal cancer and to compare it with the population norms of the given age average. We found that our patients had a higher quality of life in most areas of WHOQOL-BREF (psychological health, social relations, environment, overall QoL and health). The difference, however, was in the evaluation between the domains of the quality of life questionnaires, when patients reported their quality of life in the area of physical health as lower than the other examined areas. On the other hand, in the areas of psychological health, social relations and environment, our patients displayed a higher quality of life than respondents of the population norms of the given age average.

The difference in the quality of life between our sample of patients with laryngeal cancer and the population standards was statistically highly significant.

Despite the fact that patients have a higher quality of life, we believe it is important to continue to focus on this issue. Laryngeal cancer represents a demanding life situation both for the patients and their families, and a lot of problems have to be addressed after the treatment itself.

The risk factors (smoking, alcohol, dusty environment) of this disease are largely influenceable. Therefore, it makes sense to educate patients on a change in risk behaviour at any stage of the disease.

We recommend regularly monitoring the quality of life within follow-up care using a standardized tool to better assess the overall condition of patients and their development over time, with the possibility of interventions to maintain or improve the quality of life. Nursing care should focus not only on physical aspects, but mainly on supporting the return of patients to everyday life, managing daily activities, and adapting to the limitations of the chronic disease. Determining a subjective perception of the impact of the disease on a patient's life often leads to a better therapeutic relationship with the patient.

Very interesting - and beneficial from our point of view may be a qualitative survey, using interviews to find out the specific problems of patients with a given type of disease and treatment. We also recommend supporting preventive and screening programs that help to detect early laryngeal cancer. For instance, events such as World Voice Day, Czech Day against Cancer, World No Tobacco Day, or Head and Neck Cancer Week are organized annually in the Czech Republic. Due to the relatively frequent occurrence of this disease, we believe that the general public should be more and better informed about these prevention programmes (via television, internet, printed leaflets from general practitioners, health insurance companies, etc.).

\section{Conflict of interests}

The authors have no conflict of interest to declare.

\section{Acknowledgements}

The research was supported by a project SGS_2017_014 of the Internal Grant Agency of the University of Pardubice. 


\section{Jak hodnotí kvalitu života pacienti s karcinomem hrtanu}

\section{Souhrn}

Cílem realizované studie bylo zjistit kvalitu života u pacientů s karcinomem hrtanu po léčbě a následně ji porovnat s kvalitou života u populace daného věkového průměru.

Sběr dat byl realizován průřezovým kvantitativním šetřením s využitím standardizovaného nástroje hodnocení kvality života The World Health Organization Quality of Life Questionnaire (WHOQOL-BREF) včetně populačních norem pro věkové skupiny. Sběr dat probíhal u dispenzarizovaných pacientů na klinice otorinolaryngologie, vyhodnocena byla data od 42 pacientů, věkový průměr 70 let, 16 pacientů mělo trvalou tracheostomii. Pro statistické hodnocení kvality života mezi souborem pacientů po léčbě karcinomu hrtanu a populací daného věkového průměru byl použit $t$-test.

Zjistili jsme, že pacienti vykazovali ve všech oblastech WHOQOL-BREF (fyzické zdraví, prožívání, sociální vztahy, prostředí, celková kvalita života a zdraví) kvalitu života spíše na vyšší úrovni. Rozdíl byl v hodnocení oblasti fyzického zdraví, kdy pacienti označili kvalitu života nižší než ostatní zkoumané oblasti. Pomocí párového $t$-testu pro shodné a různé rozptyly byl prokázán statisticky vysoce významný rozdíl v subjektivním hodnocení kvality života WHOQOL-BREF mezi pacienty po léčbě karcinomu hrtanu a populací daného věkového průměru.

Z praktického hlediska (klinických intervencí) nelze jednoznačně stanovit, že by výsledky kvality života u pacientů po léčbě karcinomu hrtanu byly výrazně odlišné od hodnot populace daného věkového průměru.

Klíčová slova: karcinom hrtanu; kvalita života; populační norma kvality života; WHOQOL-BREF

\section{References}

1. Attieh AY, Searl J, Shahaltough NH, Wreikat MM, Lundy DS (2008). Voice restoration following total laryngectomy by tracheoesophageal prosthesis: Effect on patients' quality of life and voice handicap in Jordan. Health Qual Life Outcomes 26(6): 1-10. DOI: 10.1186/1477-7525-6-26.

2. Bottomley AG, Tridello G, Coens C, Rolland F, Tesselaar MET, Leemans CR, et al. (2014). An international phase 3 trial in head and neck cancer: Quality of life and symptom results. Cancer 120(3): 390-398. DOI: 10.1002/cncr.28392.

3. Czech Statistical Office (2014). Úroveň vzdělání obyvatelstva podle výsledků sčítání lidu - 2011. [online] [cit. 2017-04-02]. Available from: https://www.czso.cz/csu/czso/uroven-vzdelaniobyvatelstva-podle-vysledku-scitani-lidu-2011-xllg5xjb8q (Czech)

4. Chrobok V, Astl J, Komínek P (2004). Tracheostomie a koniotomie. Praha: Maxdorf.

5. Čiháková I, Čelakovský P (2007). Kvalita života u pacientů s tracheostomií. Otorinolaryngologie a foniatrie 56(1): 11-17.

6. Daugaard R, Kjaer T, Johansen CH, Christiansen J, Andersen E, Nielsen AI, Dalton S (2017). Association between late effects assessed by physicians and quality of life reported by headand-neck cancer survivors. Acta Oncologica 56(2): 342-347. DOI: 10.1080/0284186X.2016.1267873.

7. Dragomirecká E, Bartoňová J (2006). WHOQOL-BREF, WHOQOL-100: World Health Organization Quality of Life Assessment: Příručka pro uživatele české verze dotazníků kvality života Světové zdravotnické organizace. Praha: Psychiatrické centrum Praha.

8. Farrand P, Duncan F (2007). Generic health-related quality of life amongs patiens amploying different voice restoretion methods following total laryngectomy. Psychol Health Med 12(3): 255-256. DOI: 10.1080/13548500600665542.

9. Gourin $\mathrm{Ch}$, Starmer H, Herbert R, Frick K, Forastiere A, Quon H, et al. (2015). Quality of care and short- and long-term outcomes of laryngeal cancer care in the elderly. Laryngoscope 125(10): 2323-2329. DOI: 10.1002/lary.25378.

10. Gurková E (2011). Hodnocení kvality života. Praha: Grada.

11. Hybášek I, Vokurka J, et al. (2010). eOtorinolaryngologie. Multimediální podpora výuky klinických a zdravotnických oborů: Portál Lékařské fakulty v Hradci Králové. [online] [cit. 2018-11-06]. Available from: http://mefanet.lfhk.cuni.cz/ clanky.php?aid=18

12. IHIS CR (2017). Zdravotnická ročenka České republiky 2016. [online] [cit. 2019-17-03]. Available from: https://www.uzis.cz/ publikace/zdravotnicka-rocenka-ceske-republiky-2016 (Czech).
13. IHIS CR (2018a). Zemřelí 2017. [online] [cit. 2019-17-03]. Available from: http://uzis.cz/publikace/zemreli-2017 (Czech).

14. IHIS CR (2018b). Zdravotnická ročenka České republiky 2017. [online] [cit. 2019-17-03]. Available from: http://www.uzis. cz/publikace/zdravotnicka-rocenka-ceske-republiky-2017 (Czech).

15. Kaas J, Tóthová V (2017). Quality of life of patients who suffer from rheumatic arthritis. Kontakt 19(3): e159-e164. DOI: 10.1016/j.kontakt.2017.07.001.

16. Karlsen T, Sandvik L, Heimdal JH, Hjermstad MJ, Aarstad AKH, Aarstad HJ (2017). Health-related quality of life as studied by EORTC QLQ and voice handicap index among various patients with laryngeal disease. J Voice 31(2): 251.e17-251.e26. DOI: 10.1016/j.jvoice.2016.07.009.

17. Klozar J (2005). Speciální otorinolaryngologie. Praha: Galén.

18. Likhterov I, Ru M, Ganz C, Urken ML, Chai R, Okay D, et al. (2018). Objective and subjective hyposalivation after treatment for head and neck cancer: Long-term outcomes. Laryngoscope 128(12): 2732-2739. DOI: 10.1002/lary.27224.

19. Malá E, Vejražková E, Bielmeierová J, Jindra M, Vošmik M, Novosad J, Sobotka L (2015). Dlouhodobé sledování nutričního, klinického stavu a kvality života u nemocných s rakovinou hlavy a krku. Klinická onkologie 28(3): 200-214. DOI: 10.14735/ amko2015200.

20. Mandysová P, Škvrňáková J (2016). Diagnostika poruch polykání z pohledu sestry. Praha: Grada.

21. Nováková V, Laco J (2008). Úloha lidského papillomaviru v karcinogenezi nádorů hlavy a krku. Klinická onkologie 21(4) 141-148.

22. Paleri V, Wight RG, Owen S, Hurren A, Stafford FW (2006). Defining the stenotic post-laryngectomy tracheostoma and its impact on the quality of life in laryngectomees: development and validation of a stoma fiction questionnaire. Clin Otolaryngol 31(5): 418-424. DOI: 10.1111/j.17494486.2006.01287.x.

23. Rottenberg J, Kostřica R, Hložek J (2003). Nádory hrtanu. Onkologická péče 7(2): 6-8.

24. Šlampa P, Smilek P (2016). Nádory hlavy a krku: přehled diagnostiky a léčby maligních nádorů horních dýchacích a polykacích cest, hrtanu, slinných žláz a kůže. Praha: Mladá fronta.

25. Tan S, Duong Dinh T, Westhofen M (2016). Evaluation of gender-specific aspects in quality-of-life in patients with larynx carcinoma. Acta Oto-Laryngologica 136(12): 1201-1205. DOI: 10.1080/00016489.2016.1211319.

26. Ulrich SP, Canale SW (2005). Nursing care planning guides for adults in acute, extended and home setting, 6 . ed. Missouri: Elsevier. 
27. Van den Brink JL, De Boer MF, Pruyn JFA, Hop WCJ,

Verwoerd CDA, Moorman PW (2006). Quality of life during the first 3 months following discharge after surgery for head and neck cancer: prospective evaluation. J Otolaryngol 35(6): 395-403. DOI: 10.2310/7070.2005.0099.
28. Veldhuis D, Probst G, Marek A, Noack V, Ural A, Adamietz I, et al. (2016). Tumor site and disease stage as predictors of quality of life in head and neck cancer: a prospective study on patients treated with surgery or combined therapy with surgery and radiotherapy or radiochemotherapy. Eur Arch Otorhinolaryngol 273(1): 215-224. DOI: 10.1007/s00405-015-3496-x. 